\title{
Tissue distribution of a menthyl-conjugated oligodeoxyribonucleotide antisense to PAI-1 mRNA
}

\author{
Janusz Szemraj ${ }^{1 \#}$, Khalid N.I. Al-Nedawi² ${ }^{\sharp}$, Ewa Chabielska ${ }^{3}$, Wlodzimierz Buczko ${ }^{4}$ \\ and Zofia Pawlowska ${ }^{2 \varpi}$ \\ ${ }^{1}$ Department of Medical Biochemistry, ${ }^{2}$ Department of Molecular and Medical Biophysics, Medical University in \\ Eódź; ${ }^{3}$ Department of Biopharmacy, ${ }^{4}$ Department of Pharmacodynamics, Medical University in Bialystok,

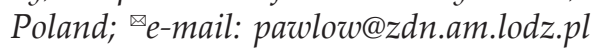

Received: 01 October, 2004; revised: 30 June, 2005; accepted: 03 October, 2005

available on-line: 21 November, 2005

\begin{abstract}
The inhibitory effect of numerous analogues of PO-16, an hexadecadeoxyribonucleotide antisense to sequences -22 to -17 of PAI-1 mRNA coding for a fragment of the signal peptide, on the expression of PAI-1 in endothelial cells, and physiological consequences of the subsequently reduced PAI-1 activity tested in vitro and in vivo, were described in our previous studies. Of particular interest was PO-16 5'-O-conjugated with menthyl phosphorothioate (MPO-16R). In this work, tissue localisation of MPO-16R labelled with $\left.{ }^{35} \mathrm{~S}\right]$ phosphorothioate at the $3^{\prime}$-end, was determined. $\left[{ }^{35}\right.$ S]MPO-16R and control $\left[{ }^{35}\right.$ S]MPO-16R-SENSE oligonucleotides were administered intravenously into 22 rats and organ distribution of the labelled bioconjugates was assessed after 24 and $48 \mathrm{~h}$. For this purpose, tissue sections were subjected to autoradiography, and quantitated by liquid scintillation after solubilisation. Overall clearance of radioactivity was already seen after $24 \mathrm{~h}$, with the radioactivity recovered mainly in the kidney and liver. A smaller fraction of radioactivity was also retained in the spleen and heart. The kidney concentration of the labelled probe was higher than that of liver by $50 \%$. The distribution of PAI- 1 mRNA in untreated rat kidney, liver, spleen and heart established by two independent techniques: Ribonuclease Protection Assay and Real-Time PCR, shows the same pattern as that observed for $\left[{ }^{35}\right.$ S]MPO-16R antisense.
\end{abstract}

Keywords: antisense oligonucleotides, tissue distribution, PAI-1

Plasminogen activator inhibitor type 1 (PAI1 ) is the major physiological inhibitor of tissue plasminogen activator (tPA) and plays a crucial role in the regulation of fibrinolysis. PAI-1 expression is upregulated under pathological conditions by a number of biologically active compounds, and in consequence its concentration in blood plasma and in extracellular matrix can be dramatically increased (van Meijer \& Pannekoek, 1995). For example, overexpression of PAI-1 is associated with thrombotic diseases, atherosclerosis, myocardial infarction, and sepsis (reviewed in van Meijer \& Pannekoek, 1995). PAI-1 controls also the extravascular activation of plasminogen occurring on the cell surface in the process involving receptors for urokinase-type plasminogen activator (uPA). PAI-1 protects tumor stromal tissue from autoproteolytic activities, and may thus substantially promote tumor growth and metastasis formation. In addition, PAI-1 activates tumor angiogenesis (Bajou et al., 1998).

Taking into consideration the importance of PAI-1 in a number of diseases, strategies aimed at its rapid inactivation may be of clinical utility. Several approaches to inhibit PAI-1 expression and activity were proposed (Levi et al., 1992; Eitzman et al., 1995; Friederich et al., 1997). One of those being the inhibition of PAI-1 synthesis using antisense oligodeoxyribonucleotides to selected regions of PAI-1 mRNA (Sawa et al., 1994; Cierniewski et al., 1995). The application of antisense oligodeoxynucleotides (ODNs) to target specific mRNA sequences and to block expression of the corresponding gene products has become commonly used technique in molecular biology (Agrawal et al., 1990). Upon uptake into the cells, the antisense ODNs hybridise to the target mRNA resulting in the formation of DNA-

\#These authors contributed equally to this work.

Abbreviations: $\mathrm{C}_{\mathrm{t}^{\prime}}$ treshold value; MPO-16R, menthyl phosphorothioate; ODN, antisense oligodeoxynucleotide; PAI-1, plasminogen activator inhibitor type 1; PS, phosphorothioate; tPA, tissue plasminogen activator; uPA, urokinase type plasminogen activator. 
RNA duplexes. Translation of the target mRNA is subsequently blocked by a variety of potential mechanisms, including degradation of the mRNA by RNase H (Agrawal et al., 1990) and inhibition of the initiation of translation (Dolnick, 1990). Antisense ODNs may also cause premature termination of transcription as well as prevent mRNA splicing (Agrawal et al., 1990).

Phosphorothioate ODNs are significantly more stable than phosphodiester ODNs in vivo because of their resistance to degradation by serum and intracellular nucleases (Agrawal et al., 1990) and were successfully applied in vivo to block gene expression within tumor cells, arterial smooth muscle cells and retinal cells (Carome et al., 1997). Successful application of ODNs in pathophysiological and therapeutic studies requires prior demonstration that there is a significant uptake of the ODNs by target tissues. In addition, knowledge about their plasma concentrations, tissue distribution and deposition is necessary for rational approach to individualise and optimise antisense regimens for experimental studies in vivo (Rifai et al., 1996). The distribution of ODNs in healthy tissues and body fluids have been generally well characterized in many species, but addition of any backbone modification, improving their stability or uptake by cells, can alter tissue distribution, residence time in cells, and interactions with proteins (Geary et al., 2001; Bijsterbosch et al., 2002). In our earlier studies we have found that PO16 5'-O-conjugated with menthyl phosphorothioate (MPO-16R) is very effective in PAI-1 inhibition. Of particular importance was the observation of its relatively high half-life in the plasma, comparable with that of the phosphorothioate oligonucleotide PS-16R. This PO-16 derivative was found to be a strong inhibitor of PAI-1 expression and activity measured both in vitro and in vivo, and in addition it showed antithrombotic properties in experimental rat model for thrombosis (Pawlowska et al., 1998; Kobylanska et al., 1999). Since phosphorothioate backbone internucleoside modifications are generally considered to be responsible for deleterious side effects such as nonsequence-specific activity, MPO-16R retaining its antisense specificity and possessing only one phosphorothioate modification was selected for further evaluation as a potential therapeutic agent. The objective of this study was to examine the distribution of menthyl conjugates of ODN sense and antisense to PAI-1 mRNA in rat tissue and organs after a single intravenous injection of its ${ }^{35}$ S-radiolabelled derivative.

\section{MATERIALS AND METHODS}

Animals. Twenty-two male Wistar rats weighing 270-300 g were used. Anaesthesia was ob- tained by pentobarbital (40 $\mathrm{mg} / \mathrm{kg}$ body mass) administered intraperitoneally. The experimental protocol was approved by the Local University Ethics Committee.

Synthesis of ${ }^{35} \mathrm{~S}$-radiolabelled oligonucleotides. Oligodeoxyribonucleotide PO-16R (GAGGGCTGAAGACATC) and PO-16R SENSE (GATGTCTTCAGCCCTC) were prepared on solid support using an ABI-394 DNA Synthesiser as described before (Kobylanska et al., 1999). For preparation of the conjugate (MPO-16R and SENSE MPO-16R), a menthol residue was connected via a phosphorothioate linkage directly to the 5'-hydroxyl group of the oligonucleotide. Radioisotope labelling of the conjugates was carried out using $\left[\alpha^{-35}\right] \mathrm{dCTP}$ and terminal deoxyribonucleotidyl transferase.

Animal experiments. A total of $0.2 \mathrm{mg}$ of $\left[{ }^{35} \mathrm{~S}\right] \mathrm{MPO}-16 \mathrm{R}$ or $\left[{ }^{35} \mathrm{~S}\right] \mathrm{MPO}-16 \mathrm{R}-\mathrm{SENSE}$ dissolved in $100 \mu \mathrm{l}$ of sterile normal saline was administered into six healthy anesthetized rats by a single bolus injection via the tail vein. The specific activity of the dosing solutions determined immediately before administration was $6 \mu \mathrm{Ci} / \mathrm{mg}$. The animals were sacrificed after anaesthesia $24 \mathrm{~h}$ or $48 \mathrm{~h}$ later. Blood was collected directly from the heart. Liver, spleen, kidney and heart were isolated and processed for detection of the radiolabelled probe. Five-micrometer thick organ tissue sections were prepared by cryosectioning or by paraffin embedding of the slices obtained from organs, which were previously fixed with buffered $10 \%$ formalin solution. All sections were attached to slides and autoradiographed using PhosphoImager Typhoon (Pharmacia, Sweden). Paraffin-embedded tissue sections were stained with hematoxylin-eosin for microscopic study.

All the excised organs were prepared blood free and weighed for liquid scintillation counting after solubilisation with Soluene-350 according to manufacturer (Packard Instrument B.V. Chemical Operation). Briefly, $100 \mathrm{mg}$ aliquots of each organ were treated with $1 \mathrm{ml}$ of Soluene-350 for $4 \mathrm{~h}$ at $50^{\circ} \mathrm{C}$ followed by the addition of $10 \mathrm{ml}$ of HionicFluor containing a chemiluminescence inhibitor for Soluene-350. For whole blood, $0.2 \mathrm{ml}$ of a blood sample was mixed with $1 \mathrm{ml}$ of Soluene-350 and then incubated for $30 \mathrm{~min}$ at $50^{\circ} \mathrm{C}$. Afterwards, $30 \% \mathrm{H}_{2} \mathrm{O}_{2}$ was added dropwise and incubation continued for $30 \mathrm{~min}$ at $50^{\circ} \mathrm{C}$, followed by addition of $10 \mathrm{ml}$ Hionic-Fluor. Blood cells were isolated by centrifugation $(120 \times g)$ of $1 \mathrm{ml}$ whole blood. The cells were treated like whole blood and $0.5 \mathrm{ml}$ of plasma was added to $10 \mathrm{ml}$ of Pico-Fluor 40. The radioactivity of each organ was determined by liquid scintillation (Beckman Instruments, USA) and the values were expressed as the percentage of dose per gram of tissue normalized to the dose per gram of animal.

Ribonuclease protection assay. DNA was purified by phenol/chloroform extraction, precipitated 
with ethanol and dissolved in TE buffer (10 mM Tris/HCl, $1 \mathrm{mM}$ EDTA) at a concentration of $1 \mathrm{mg} /$ $\mathrm{ml}$. Radiolabelled probe was synthesized by the procedure of Melton et al. (1984). Reaction conditions were as follows: $0.5 \mu \mathrm{g}$ of linearized DNA, $10 \mathrm{mM}$ dithiothreitol, $500 \mu \mathrm{M}$ each of GTP, CTP, ATP, $8 \mu \mathrm{M}$ UTP and $1.25 \mu \mathrm{M}\left[\alpha^{32} \mathrm{P}\right] \mathrm{UTP}(800 \mathrm{Ci} / \mathrm{mM})$ in transcription buffer $(40 \mathrm{mM}$ Tris/ $\mathrm{HCl}, \mathrm{pH} 7.5,6 \mathrm{mM}$ $\mathrm{MgCl}_{2}, 2 \mathrm{mM}$ spermidine, $\left.5 \mathrm{mM} \mathrm{NaCl}\right), 40 \mathrm{U}$ RNase inhibitor (Promega Corp., Madison, WI, USA), $10 \mathrm{U}$ bacteriophage Sp6 polymerase (Promega Corp., Madison, WI, USA) in a total volume of $20 \mu \mathrm{l}$. After $1 \mathrm{~h}$ incubation at $37^{\circ} \mathrm{C}$ RNase-free DNase was added and incubation continued for $10 \mathrm{~min}$ at $37^{\circ} \mathrm{C}$. Single-stranded RNA was phenol/chloroform extracted, precipitated with ethanol and dissolved in hybridization buffer (20 mM Tris/ $\mathrm{HCl}, \mathrm{pH} 7.5,20 \mathrm{mM}$ EDTA, $0.6 \mathrm{M} \mathrm{NaCl}, 1 \% \mathrm{SDS})$.

Nuclei were isolated from tissues according to Srivastava and Schonfeld (1994). Pellet containing pure nuclei was resuspended in storage buffer: 20 mM Tris/ $\mathrm{HCl}, \mathrm{pH}$ 7.9, 75 mM NaCl, 0.5 mM DTT, $0.125 \mathrm{mM}$ phenylmethylsulfonyl fluoride (PMSF), $50 \%$ glycerol. Elongation buffer $(2 x, 100 \mu \mathrm{l}), 6 \mu \mathrm{l}$ of $100 \mathrm{mM}$ solution of nucleotide mix (GTP, ATP, CTP, UTP), $10^{7}$ nuclei in storage buffer, $40 \mathrm{U}$ of RNase inhibitor (RNasin, Promega, Madison, WI, USA), 40 ng sense or antisense oligonucleotides were added to a total volume of $200 \mu \mathrm{l}$. Transcription reaction proceeded for $45 \mathrm{~min}$ at $26^{\circ} \mathrm{C}$ and was stoped by addition of $100 \mathrm{U}$ of DNase I (RNase free). Incubation was carried out for additional $10 \mathrm{~min}$. Samples were then treated with $2 \mu \mathrm{l}$ proteinase $\mathrm{K}(10 \mathrm{mg} / \mathrm{ml})$ for $30 \mathrm{~min}$ at $56^{\circ} \mathrm{C}$, extracted by phenol/chloroform and precipitated. After precipitation RNA samples were dissolved in TE buffer and used for hybridization. For each assay reaction we used $10 \mu \mathrm{g}$ of total RNA isolated from rat tissues (three rats in each group) by the method of Chomczynski and Sacchi (1987). Radiolabelled probe (20 pg) and $10 \mu \mathrm{g}$ t-RNA in 10 $\mathrm{ml}$ hybridization buffer were incubated for $17 \mathrm{~h}$ at $75^{\circ} \mathrm{C}$. Single-stranded RNA was digested by adding $250 \mu \mathrm{l}$ of a solution containing $50 \mu \mathrm{g} / \mu \mathrm{l}$ RNase A, $200 \mathrm{U} / \mathrm{ml}$ RNase TI (Worthington Biochemicals, Lakewood, CO, USA) and incubation for $1 \mathrm{~h}$ at $32^{\circ} \mathrm{C}$. After phenol/chloroform extraction and ethanol precipitation radiolabelled RNA was analyzed by electrophoresis on $6 \%$ polyacrylamide gel. The gel was dried at $80^{\circ} \mathrm{C}$ and then exposed overnight to Kodak XAR-5 film.

Quantitative real-time PCR analysis. Total RNA $(1 \mu \mathrm{g})$ was extracted from the liver, spleen, heart and kidney tissues using Trizol reagent (Life Technologies, Inc.), and was used directly for cDNA synthesis using the TaqMan Reverse Transcription Reagents kit (Applied Biosystems, Foster City, CA, USA) according to the manufacturer's protocol. PAI-1 and $\beta$-actin expression was quantified by real-time RT-
PCR using an ABI Prism 7000 Sequence Detection System (Applied Biosystems) according to the manufacturer's protocol. Briefly, 2.5, 2.0, 1.5, 1.0, 0.5 and $0.25 \mu \mathrm{l}$ of synthesized cDNA was amplified in triplicate for both $\beta$-actin and each of the target genes to create a standard curve. Likewise, $2 \mu \mathrm{l}$ of cDNA was amplified in triplicate for all isolated samples for each primer/probe combination, and for $\beta$-actin. Each sample was supplemented with appropriate forward and reverse primers at $0.3 \mu \mathrm{M}$, fluorescent probe, and made up to $50 \mu \mathrm{l}$ using $\mathrm{qPCR}^{\mathrm{TM}}$ Mastermix for SYBR Green I (Eurogentec, Seraing, Belgium). All the following PCR primers were designed using PrimerExpress software (Applied Biosystems): forward 5' TGCTGGTGAATGCCCTCTACT 3', reverse 5' CGG TCATTCCCAGGTTCTCTA 3', forward 5' CGTACCACTGGCATCGTGAT 3', reverse 5' GTGTTGGCGTACAGGTCT TTG 3', specific for mRNA of PAI-1 and $\beta$-actin, respectively. Each target probe was amplified in a separate 96-well plate. All samples were incubated at $50^{\circ} \mathrm{C}$ for $2 \mathrm{~min}$ and at $95^{\circ} \mathrm{C}$ for $10 \mathrm{~min}$ and then cycled at $95^{\circ} \mathrm{C}$ for $30 \mathrm{~s}, 56^{\circ} \mathrm{C}$ for $1 \mathrm{~min}$ and $72^{\circ} \mathrm{C}$ for $1 \mathrm{~min}$ for 40 cycles. SYBR Green I fluorescence emission data were measured and mRNA levels were quantified using the critical threshold $\left(C_{t}\right)$ value. Analyses were performed with ABI Prism 7000 (SDS Software). Controls without reverse transcription and with no template cDNA were performed with each assay. To compesate for variations in input RNA amounts and efficiency of reverse transcription, $\beta$-actin mRNA was quantified and the results were normalized to these values. Relative gene expression levels were obtained using the $\Delta \Delta C_{t}$ method (Winer et al., 1999). Amplificationspecific transcripts were further confirmed by obtaining melting curve profiles.

\section{RESULTS AND DISCUSSION}

Several factors may affect the inhibitory efficiency of antisense ODNs in controlling gene expression in vivo. These include the physicochemical properties of the ODNs determining their partition between the liquid phase and the lipid bilayer of the cell membranes. They also include structural features of cell membranes that control permeability to ODNs and limit the kinetics of their transport into various cells. ODNs distribution studies published so far have shown that radiolabelled antisense oligonucleotides administered intravenously are usually distributed evently throughout the body tissues and that the intracellular fate of the oligonucleotides strongly depends on backbone modification and their sequence-dependent ability to form tetraplex structures (Szklarczyk \& Kaczmarek, 1997; Manoharan, 2002; Maszewska et al., 2002). Our present studies were focused on describing the organ location of the 
strong anti-PAI-1 ODN MPO-16R, a phosphorothioate analogue of a hexadecadeoxyribonucleotide complementary to rat PAI-1 mRNA. It blocked PAI-1 expression in endothelial cells and caused a systemic inhibition of PAI-1 expression in rats as measured in blood plasma, in platelets, and after thrombus formation (Cierniewski et al., 1995; Pawlowska et al., 1998; Kobylanska et al., 1999). Since the optimal period of time for detection of its inhibitory effect on PAI-1 activity was $24 \mathrm{~h}$ after bolus injection, in the present study, organ distribution of $\left[{ }^{35} \mathrm{~S}\right] \mathrm{MPO}-16 \mathrm{R}$ was tested in rats 24 and $48 \mathrm{~h}$ after intravenous administration. For this purpose, animals were sacrificed and different organ tissues were processed for detection of radioactivity content. Figure 1A shows tissue levels of $\left[{ }^{35} \mathrm{~S}\right] \mathrm{MPO}-16 \mathrm{R}$ retained in $1 \mathrm{~g}$ of the different organs of rat, expressed as the percentage of the dose detected per $1 \mathrm{~g}$ of the whole animal. Kidney appeared to be the main target for the antisense $\left[{ }^{35} \mathrm{~S}\right] \mathrm{ODN}$. The accumulation of the radioactive probe in the kidney measured after $24 \mathrm{~h}$ was $21 \%$. After $48 \mathrm{~h}$ the probe was still detectable at $16 \%$. Liver and spleen showed significantly lower accumulation, $11 \%$ and $10 \%$ after $24 \mathrm{~h}$ and $4 \%$ and $7 \%$ after $48 \mathrm{~h}$, respectively. Smaller fractions were accumulated in the heart, about $4 \%$ after $24 \mathrm{~h}$ and $2 \%$ after $48 \mathrm{~h}$. Taking into consideration the total mass of each organ, kidney appears as the main target organ for ${ }^{35}$ S-MPO-16R. The sense probe showed notably

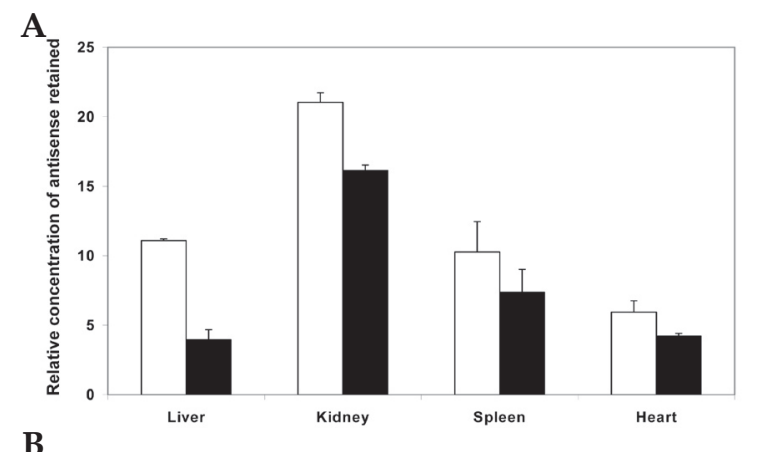

B

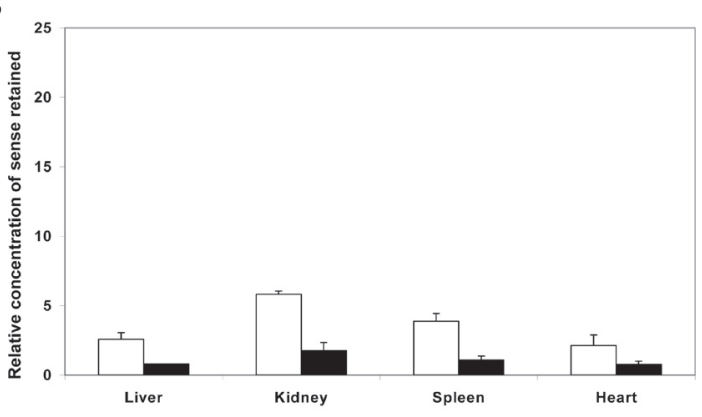

Figure 1. Tissue distribution of antisense (A) and sense (B) ${ }^{35}$ S-labelled MPO-16R conjugates.

Each probe was administered into two groups of three animals each. After $24 \mathrm{~h}$ (empty bars) or $48 \mathrm{~h}$ (filled bars) organs were collected, solubilised with Soluene-350 and radioactivity was determined by liquid scintillation. Values are the radioactivity content per gram of tissue expressed as the percentage of total dose applied per gram of whole animal, \pm S.D. lower percentages of accumulation (Fig. 1B). After $24 \mathrm{~h}$ the accumulation was 5.8, 3.8, 2.5 and $2.1 \%$ in kidney, liver, spleen and heart, respectiveley, but after $48 \mathrm{~h}$ very low fractions of the sense probe persisted $(1.7,0.8,1$ and $0.7 \%$ in kidney, liver, spleen and heart, respectively). The high retention level of radioactivity in specific rat tissues after $24 \mathrm{~h}$ since the administration of MPO-16R correlates well with the time necessary to obtain the highest reduction in PAI-1 activity in the plasma, determined in our previous study (Pawlowska et al., 1998). Furthermore, it appears that the menthyl-modified PO-16R does not undergo rapid cellular exocytosis and the persisting radioactivity derived from the labelled probe is substantial after $24 \mathrm{~h}$ or even after $48 \mathrm{~h}$ since the administration.

The radioactivity detected within the tested samples is equally distributed as evidenced by autoradiography of the frozen sections (Fig. 2).

Figure 3 shows the percentage of radioactivity recovered in $1 \mathrm{ml}$ of whole blood, blood cells and blood plasma after 24 and $48 \mathrm{~h}$ for the both tested probes.

Ribonuclease protection assay (RPA) was performed to measure PAI-1 mRNA level in organs, from animals treated with either oligonucleotide. The
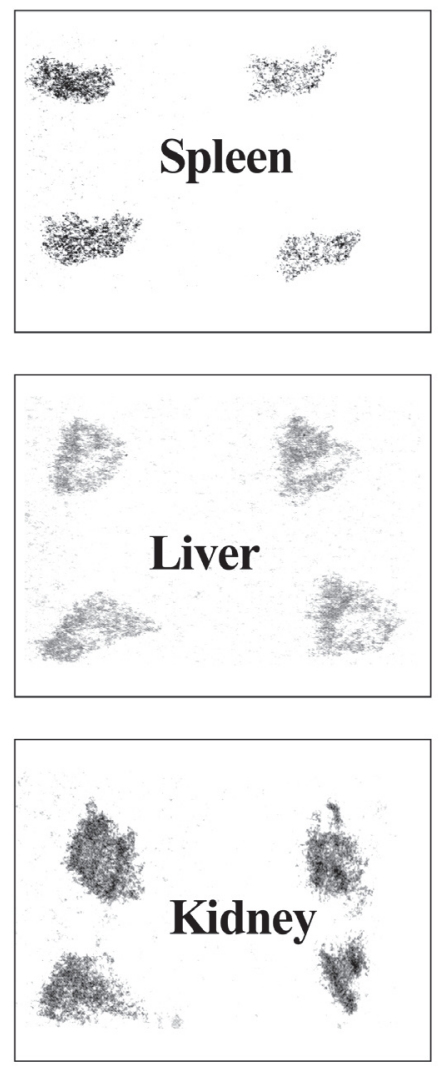

Figure 2. Distribution of radioactivity in sections of rat spleen, liver, and kidney $24 \mathrm{~h}$ after antisense ${ }^{35}$ S-labelled MPO-16R administration.

Autoradiography was done using Phosphoimager Typhoon (Pharmacia, Sweden). Representative images are shown. 


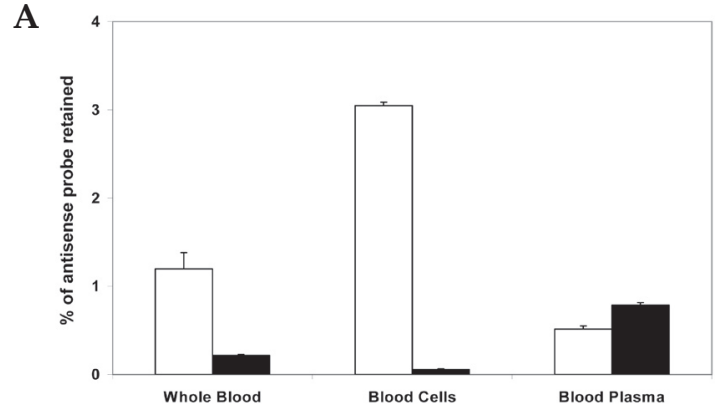

B

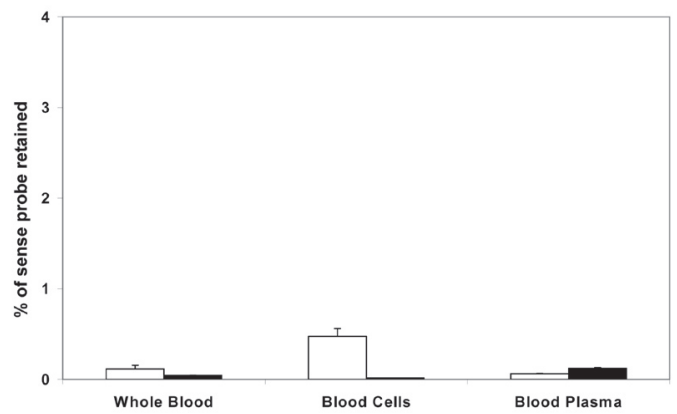

Figure 3. Distribution of antisense (A) and sense (B) ${ }^{35} \mathrm{~S}-$ labelled MPO-16R probes in blood.

Probe was injected in two groups of three animals each. Animals were sacrificed after $24 \mathrm{~h}$ (empty bars) or after 48 $\mathrm{h}$ (filled bars). Blood was collected from each animal and fractionated for cells and plasma, lysed with Soluene-350 and radioctivity was determined by liquid scintillation. Values are expressed as a percentage of a dose per gram of tissue in one $\mathrm{ml}$ of each blood component, \pm S.D.

antisense oligonucleotide decreased the cellular level of specific mRNA in all tested organs (Fig. 4A).

Figure $4 \mathrm{~B}$ shows that the sense probe had no effect on the transcription level. The antisense probe inhibited transcription in both liver and kidney, with a higher degree of inhibition in the liver than in the kidney. According to decreased inhibition by antisense oligonucleotide detected in studied tissue, the
A
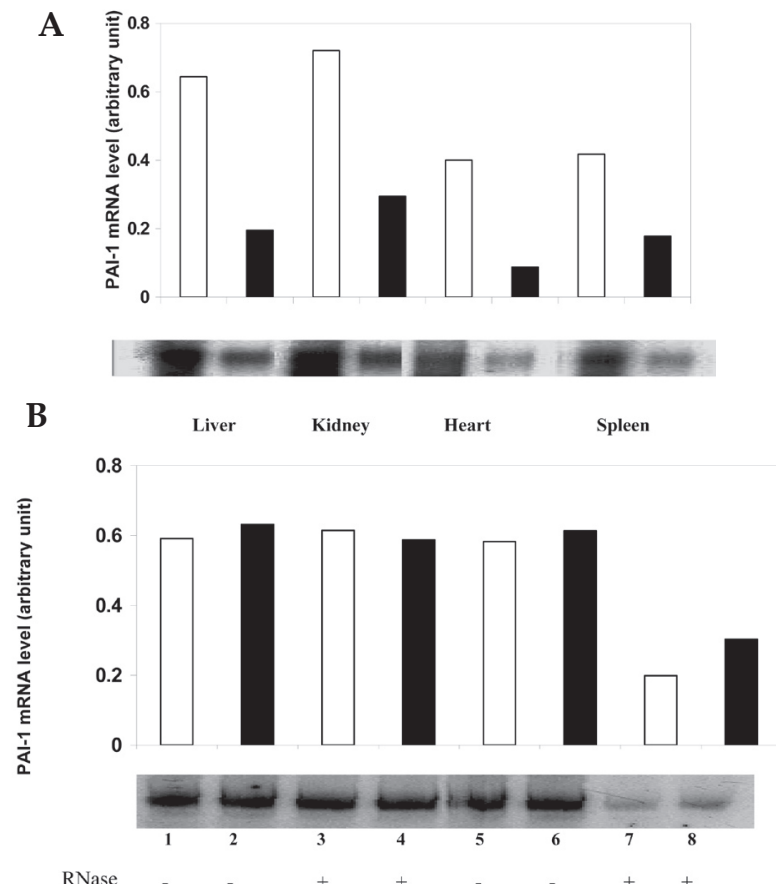

Figure 4. Ribonuclease protection assay

(A) Tissue specific transcription of PAI-1 gene in the presence of antisense probe in liver, kidney, heart, and spleen without (empty bars) or with (filled bars) RNase treatment, $24 \mathrm{~h}$ after antisense administration (B). The effect of sense probe (lanes 1-4) and antisense probe (lanes 5-8) without treatment with RNase (lanes 1, 2, 5, 6) or with RNase (lanes 3, 4, 7, 8). Tissue specific transcription level of PAI-1 gene in liver (empty bars) and kidney (filled bars). Typical autoradiograms and their densitograms from three experiments are shown.

order was as follows: heart, spleen, liver and kidney, which means that the amount of PAI-1 mRNA was on the opposite direction by means of kidney, liver, spleen, and heart. The measurements of radioactivity level in organs, autoradiograms of tissue sections

B

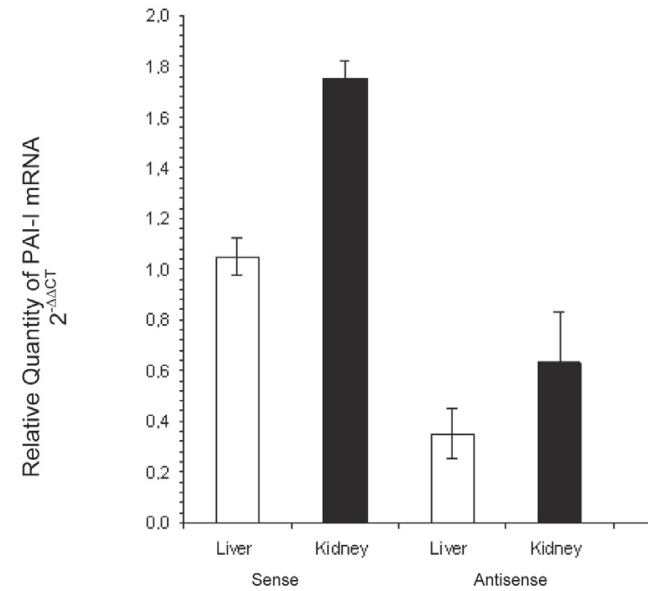

Figure 5. Quantitative real-time PCR analysis of tissue specific expression of PAI-1 mRNA.

(A) PAI-1 mRNA level after antisense probe application in liver, kidney, heart and spleen. Organ tissue sections came from animals sacrificed after $24 \mathrm{~h}$. (B) PAI-1 mRNA level in the presence of sense and antisense probe in liver and kidney cells. Tissue specific transcription of PAI-I gene in liver (empty bars) and kidney (filled bars). The graphs show the average \pm S.D. of three experiments. 
and the ribonuclease protection assay showed clear compatibility of the transcription level of PAI-1 gene and the accumulation of the MPO-16R antisense in the studied organs. Our observations on organ distribution of MPO-16R in rat after systemic administration are consistent with earlier data describing the location of PAI-1 mRNA in rat organs. PAI-1 mRNA was found in many rat tissues and organs, i.e. in the liver, kidney, heart, spleen and testis (Nargolwalla et al., 1990; Quax et al., 1990; Konkle et al., 1992; Keeton et al., 1993; van Meijer \& Pannekoek, 1995; Oikawa et al., 1997). The most significant regulation of PAI1 mRNA was observed throughout the kidney (Oikawa et al., 1997). In order to confirm that the tissue concentration of PAI-1 mRNA and MPO-16R are similar, the mRNA abundance was determined by quantitative real-time PCR analysis. (Fig. 5A, B) The level of PAI-1 mRNA determined in tissues correlated positively with the degree of antisense probe retention. MPO-16R sense had no effect on the level of PAI-1 gene transcription.

Thus, the similarities in the distribution of MPO-16R and PAI-1 mRNA, particularly the highest concentration of the antisense ODN in kidney, the organ showing the highest level of PAI-1 mRNA, indicate that this accumulation of $\left[{ }^{35} \mathrm{~S}\right] \mathrm{ODN}$ may result from the sequence-specific interaction with PAI1 mRNA.

We also provide evidence that by systemic application of antisense oligonucleotides it is possible to cause an effective inhibition of PAI-1 expression in all organs, with the highest degree of inhibition in kidney and liver. These data strongly suggest that the MPO-16R oligonucleotide antisense to PAI1 mRNA should be considered as a new potential agent for targeted fibrinolytic and cancer treatment therapy, especially at sites of the highest PAI-1 expression.

\section{Acknowledgements}

This study was performed with a contribution of the Centre of Excellence MolMed supported by the European Commission and a KBN SPUB grant.

The authors thank Dr. Maria Koziolkiewicz (Department of Bioorganic Chemistry, Centre of Molecular and Macromolecular Studies PAS) for providing oligonucleotides.

\section{REFERENCES}

Agrawal S, Mayrand SH, Zamecnik PC, Pederson T (1990) Site-specific excision from RNA by RNase $\mathrm{H}$ and mixed-phosphate-backbone oligodeoxynucleotides. Proc Natl Acad Sci USA 87: 1401-1415.

Bajou K, Noel A, Gerard RD, Masson V, Brunner N, HolstHansen C, Skobe M, Fusenig NE, Carmeliet P, Collen D, Foidart JM (1998) Absence of host plasminogen ac- tivator inhibitor 1 prevents cancer invasion and vascularization. Nat Med 8: 923-928.

Bijsterbosch MK, Manoharan M, Dorland R, Van Veghel R, Biessen EAL, Van Berkel TJC (2002) bis-Cholesterylconjugated phosphorothioate oligodeoxynucleotides are highly selectively taken up by the liver. J Pharmacol Exp Ther 302: 619-626.

Carome MA, Kang Y-H, Bohen EM, Nicholson DE, Carr FE, Kiandoli LC, Brummel SE, Yuan CM (1997) Distribution of the cellular uptake of phosphorothioate oligodeoxynucleotides in the rat kidney in vivo. Nephron 75: 82-87.

Chomczynski P, Sacchi N (1987) Single-step method of RNA isolation by acid guanidinium thiocyanate-phenol-chloroform extraction. Anal Biochem 162: 156-159.

Cierniewski CS, Babinska A, Swiatkowska M, Wilczynska M, Okruszek A, Stec WJ (1995) Inhibition by modified oligodeoxynucleotides of the expression of type- 1 plasminogen activator inhibitor in human endothelial cells. Eur J Biochem 227: 494-509.

Dolnick BJ (1990) Antisense agents in pharmacology. Biochem Pharmacol 40: 671-675.

Eitzman DT, Fay WP, Lawrence DA, Francis-Chmura AM, Shore JD, Olson ST, Ginsburg D (1995) Peptide-mediated inactivation of recombinant and platelet plasminogen activator inhibitor-1 in vitro. I Clin Invest 95: 2416-2420.

Friederich PW, Levi M, Biemond BJ, Charlton P, Templeton $\mathrm{D}$, van Zonneveld AJ, Bevan P, Pannekoek $\mathrm{H}$, ten Cate JW (1997) Novel low-molecular-weight inhibitor of PAI-1 (XR5118) promotes endogenous fibrinolysis and reduces postthrombolysis thrombus growth in rabbits. Circulation 96: 916-921.

Geary RS, Watanabe TA, Truong L, Freier S, Lesnik EA, Sioufi NB, Sasmor H, Manoharan M, Levin AA (2001) Pharmacokinetic properties of 2'-O-(2-methoxyethyl)modified oligonucleotide analogs in rats. J Pharmacol Exp Ther 296: 890-897.

Goodarzi G, Watabe M, Watabe K (1992) Organ distribution and stability of phosphorothioated oligodeoxyribonucleotides in mice. Biopharm Drug Dispos 13: 221-227.

Keeton M, Eguchi Y, Sawdey M, Ahn C, Loskutoff DJ (1993) Cellular localization of type 1 plasminogen activator inhibitor messenger RNA and protein in murine renal tissue. Am J Pathol 142: 59-70.

Kobylanska A, Pluskota E, Swiątkowska M, Wojcik M, Cierniewska-Cieslak A, Krakowiak A, Boczkowska M, Pawlowska Z, Okruszek A, Koziolkiewicz M, Cierniewski C, Stec WJ (1999) Inhibition of plasminogen activator inhibitor release in endothelial cell cultures by antisense oligodeoxyribonucleotides with a $5^{\prime}$-end lipophilic modification. Acta Biochim Polon 46: 679-691.

Konkle BA, Schuster SJ, Kelly MD, Harjes K, Hassett DE, Bohrer M, Tavassoli M (1992) Plasminogen activator inhibitor-1 messenger RNA expression is induced in rat hepatocytes in vivo by dexamethasone. Blood 79: 2636-2642.

Levi M, Biemond BJ, van Zonneveld AJ, ten Cate JW, Pannekoek H (1992) Inhibition of plasminogen activator inhibitor-1 activity results in promotion of endogenous thrombolysis and inhibition of thrombus extension in models of experimental thrombosis. Circulation 85: 305 312.

Manoharan M (2002) Oligonucleotide conjugates as potential antisense drugs with improved uptake, biodistribution, targeted delivery, and mechanism of action. Antisense Nucleic Acid Drug Dev 12: 103-128.

Maszewska M, Kobylanska A, Gendaszewska-Darmach E, Koziolkiewicz M (2002) Bromodeoxyuridine-labelled 
oligonucleotides as tools for oligonucleotide uptake studies. Antisense Nucleic Acid Drug Dev 12: 379-391.

Melton DA, Krieg PA, Rebagliati MR, Maniatis T, Zinn K, Green MR (1984) Efficient in vitro synthesis of biologically active RNA and RNA hybridization probes from plasmid containing a bacteriophage Sp6 promoter. $\mathrm{Nu}$ cleic Acids Res 12: 7035-7056.

Nargolwalla C, McCabe D, Fritz IB (1990) Modulation of levels of messenger RNA for tissue-type plasminogen activator in rat Sertoli cells, and levels of messenger RNA for plasminogen activator inhibitor in testis peritubular cells. Mol Cell Endocrinol 70: 73-80.

Oikawa T, Freeman M, Lo W, Vaughan DE, Fogo A (1997) Modulation of plasminogen activator inhibitor-1 in vivo: a new mechanism for the anti-fibrotic effect of renin-angiotensin inhibition. Kidney Int 51: 164-172.

Pawlowska Z, Pluskota E, Chabielska E, Buczko W, Okruszek A, Stec WJ, Cierniewski CS (1998) Phosphorothioate oligodeoxyribonucleotides antisense to PAI-1 mRNA increase fibrinolysis and modify experimental thrombosis in rats. Thromb Haemost 79: 348-353.

Quax $\mathrm{PH}$, van den Hoogen CM, Verheijen JH, Padro T, Zeheb R, Gelehrter TD, van Berkel TJ, Kuiper J, Emeis JJ (1990) Endotoxin induction of plasminogen activator and plasminogen activator inhibitor type $1 \mathrm{mRNA}$ in rat tissues in vivo. J Biol Chem 265: 15560-15563.
Rifai A, Brysch W, Fadden K, Clark J, Schlingensiepen KH (1996) Clearance kinetics, biodistribution, and organ saturability of phosphorothioate oligodeoxynucleotides in mice. Am J Pathol 149: 717-725.

Sawa H, Sobel BE, Fujii S (1994) Inhibition of type-1 plasminogen activator inhibitor production by antisense oligonucleotides in human vascular endothelial and smooth muscle cells. J Biol Chem 269: 14149-14152.

Srivastava RA, Schonfeld G (1994) Quantification of absolute amounts of cellular messenger RNA by RNA-excess solution hybridization. Methods Mol Biol 31: 273279.

Szklarczyk A, Kaczmarek L (1997) Pharmacokinetics of antisense analogues in the central nervous system. Neurochem Int 31: 413-423.

van Meijer M, Pannekoek H (1995) Structure of plasminogen activator inhibitor 1 (PAI-1) and its function in fibrinolysis: an update. Fibrinolysis 9: 261-276.

Winer J, Jung CK, Shackel I, Williams PM (1999) Development and validation of real-time quantitative reverse transcriptase-polymerase chain reaction for monitoring gene expression in cardiac myocytes in vitro. Anal Biochem 270: 41-49. 